\title{
Degradation of Adsorbed Transforming DNA by Haemophilus influenzae
}

\author{
By J. H. STUY AND BEATRIX VAN DER HAVE \\ Department of Biological Science, Florida State University, \\ Tallahassee, Florida 32306, U.S.A.
}

(Accepted for publication 4 December 1970)

SUMMARY

Radioactively labelled transforming DNA is rapidly and irreversibly adsorbed by competent Haemophilus influenzae bacteria. Upon incubation, about $20 \%$ is degraded within $15 \mathrm{~min}$. to acid-soluble products. Thereafter there is little change. Degradation products were identified by Dowex column chromatography as inorganic phosphate, nucleosides, small and large oligonucleotides. Mononucleotides were not observed. These products were always found in the medium while little, if any, was observed in the cells. It is concluded that the degradation process may take place outside the cells. It involves at least an endonuclease and a phosphatase.

\section{INTRODUCTION}

Irreversible adsorption of transforming DNA by competent bacteria is followed by a partial degradation to small molecular weight products (Diplococcus pneumoniae: Lacks, 1962; Fox \& Allen, 1964; Lacks, Greenberg \& Carlson, 1967; Haemophilus influenzae: Stuy, 1965; Notani \& Goodgal, 1966). Lacks et al. (1967) reported that the breakdown products were predominantly inorganic phosphate and $5^{\prime}$ mononucleotides. They speculated that a surface exonuclease was active in the penetration process of the transforming DNA into the cells. The conversion of such DNA into single strands (Lacks, 1962) is then understandable. Single donor DNA strands have never been found following irreversible binding by competent $H$. influenzae (Stuy, 1965; Notani \& Goodgal, 1966). Thus it became important to understand the biochemical mechanism of DNA degradation after adsorption by this organism.

This study will show that the breakdown process differs from that described for Diplococcus pneumoniae. It involves at least the action of an endonuclease and a phosphatase. It may occur outside the bacteria.

\section{METHODS}

Cultures, media and transformation techniques. These have been described (Stuy, 1962, 1965). Competent bacteria at $10^{9} / \mathrm{ml}$. were prepared by centrifuging anaerobically held bacteria and shaking them gently at $30^{\circ}$ during $60 \mathrm{~min}$. in 2 vol. of $\mathrm{O} . \mathrm{I} \mathrm{M}-$ $\mathrm{NaCl}$ L-broth $10 \%(\mathrm{v} / \mathrm{v})$.

Radioactively labelled DNA. Streptomycin-resistant (str-r) bacteria were grown in a chemically defined medium MI (Herriott, Meyer, Vogt \& Moda, I970) without inorganic phosphate but with $3 \%(\mathrm{v} / \mathrm{v})$ brain-heart infusion. Carrier-free [ $\left.{ }^{32} \mathrm{P}\right]$ phosphoric acid was added to give $70 \mu \mathrm{Ci} / \mathrm{ml}$. For additional ${ }^{3} \mathrm{H}$-labelling, 5 -fluorodeoxyuridine 
(3 $\mu \mathrm{g} . / \mathrm{ml}$; ; a gift from Hoffmann-La Roche), $\left[{ }^{3} \mathrm{H}\right]$ thymidine and $\left[{ }^{3} \mathrm{H}\right]$ deoxyadenosine were added (both at Io $\mu \mathrm{Ci} / \mathrm{ml}$.). Washed cells were lysed at $42^{\circ}$ with I \% sodium lauryl sulphate in SSC (0.15 M-NaCl; 0.0I5 M-sodium citrate, $\mathrm{pH} 7.4$ ) containing $0.1 \mathrm{mg} . / \mathrm{ml}$. of pronase (preself-digested and heated at $60^{\circ}$ for $10 \mathrm{~min}$.). The suspension was made $\mathrm{IM}$ with respect to $\mathrm{NaCl}$, shaken with chloroform and centrifuged in the cold. The supernatant was dialysed against SSC, treated with RNase (Io $\mu \mathrm{g}$. $/ \mathrm{ml}$., 60 min. at $37^{\circ}$ ), shaken with chloroform and dialyzed against SSC. Purification was completed by banding in a $7 \mathrm{M}$-CsCl gradient. All our preparations were quantitatively adsorbed by competent bacteria. Treatment with RNase produced $2 \%$ acid-soluble products. Treatment with DNAse (Io $\mu \mathrm{g} . / \mathrm{ml}$, $60 \mathrm{~min}$. at $37^{\circ}$ in the presence of $5 \mathrm{mM} \mathrm{CaCl} \mathrm{Cl}_{2}$ ) produced $60 \%$ or more acid-soluble products. When centrifuged in a 5 to $20 \%$ sucrose gradient at $25,000 \mathrm{rev}$./min. (Newman \& Stuy, I97I), the DNA sedimented in a broad band about $\mathrm{I} \cdot 8$ times as fast as bacteriophage $\lambda$ DNA.

DNA uptake. Competent cells at $10^{9} / \mathrm{ml}$. were exposed to labelled DNA for 2 to 3 min. at $30^{\circ}$ and then rapidly chilled in an ice water bath. The bacteria were centrifuged in the cold and washed with $0.3 \mathrm{M}-\mathrm{NaCl}$ in Eugon broth and then with $0.1 \mathrm{M}$ $\mathrm{NaCl}$ in broth. These suspensions release no significant amounts of radioactivity when incubated with DNase (10 $\mu \mathrm{g}$. $/ \mathrm{ml}$., I min. at $37^{\circ}$ ). Initial binding by the cells was always between 60 and $90 \%$ but washing removed about one-half of the adsorbed radioactivity.

Degradation of adsorbed $D N A$. Washed bacteria were suspended in appropriate media and shaken at $37^{\circ}$. Samples were withdrawn and chilled. Two drops of $1 \%$ serum albumin were added, and the suspensions were then made $0.5 \mathrm{M}$ with respect to perchloric acid. They were centrifuged after standing Io min. in the cold. The supernatants were assayed for radioactivity. In some experiments, withdrawn samples were first centrifuged in the cold to remove the bacteria before being treated with perchloric acid.

Chromatographic analysis of DNA breakdown products. Dowex IX-8 columns (10X I cm. diameter; 100 to 200 mesh) were washed with $20 \mathrm{ml}$. of $\mathrm{N}-\mathrm{HCl}$ and then with $80 \%$ acetic acid until no u.v. adsorbing material eluted. They were then washed with either $2.2 \mathrm{M}$-ammonium acetate $\mathrm{pH} 4.2(20 \mathrm{ml}$.) and $100 \mathrm{ml}$. of the same salt at $50 \mathrm{mM}$, or with ammonium acetate at $2 \cdot 2 \mathrm{M}$ and $\mathrm{pH} 4 \cdot 2,100 \mathrm{mM}$ and $\mathrm{pH} 6.8(20 \mathrm{ml}$.) and $50 \mathrm{~mm}$ and $\mathrm{pH} \mathrm{9.2}(500 \mathrm{ml}$.).

Perchloric acid-treated suspensions were neutralized with $\mathrm{KOH}$ and the $\mathrm{KClO}_{4}$ removed. Then $250 \mu \mathrm{g}$. each of the four $5^{\prime}$ deoxynucleotides was added to the equivalent of 2 to $4 \mathrm{ml}$. of initial suspension. The $\mathrm{pH}$ was raised to $9 \cdot 2$ and the solution applied to a freshly washed column adjusted at $\mathrm{pH} 9 \cdot 2$. The column was washed with Io $\mathrm{ml}$. of ammonium acetate at $100 \mathrm{mM}$ and $\mathrm{pH} \mathrm{9.2,} 100$ to $200 \mathrm{ml}$. of the salt at $100 \mathrm{mM}$ and $\mathrm{pH} 6.8$ (to remove dissolved carbonate) and then with $20 \mathrm{ml}$. of the salt at $100 \mathrm{mM}$ and $\mathrm{pH}_{4} \cdot 2$. This washing removed nearly all of the u.v. adsorbing material originally present in broth. The added reference mononucleotides could then be clearly observed. The column was then eluted with $300 \mathrm{ml}$. of a linear ammonium acetate gradient running from 100 to $2 \cdot 2 \mathrm{M}$ at $\mathrm{pH} 4 \cdot 2$. In this modified procedure of Lacks et al. (1967) the four nucleotides are eluted as follows: deoxycytidylic acid at $0.55 \mathrm{M}$, thymidylic acid at $0.95 \mathrm{M}$, deoxyadenylic acid at $\mathrm{I} \cdot 2 \mathrm{M}$ and deoxyguanylic acid at $\mathrm{I} \cdot 9 \mathrm{M}$ acetate. Inorganic phosphate elutes between 0.8 and $\mathrm{I} \cdot \mathrm{I} \mathrm{M}$, i.e. just ahead of adenylic acid or thymidylic acid. 
Perchloric acid-treated suspensions of bacteria incubated in salt solutions or chemically defined medium were applied to columns adjusted to $\mathrm{pH} 4 \cdot 2$ and then eluted with the acetate gradient. Inorganic phosphate now eluted behind thymidylic acid with adenylic acid. This made detection of ${ }^{3} \mathrm{H}$-labelled AMP impossible.

The columns were finally washed with $25 \mathrm{ml}$. of either $\mathrm{N}-\mathrm{HCl}$ or $\mathrm{NaOH}$. This eluted some u.v.-adsorbing material.

Radioactivity measurements. Phosphate was measured on planchets in a Beckman Lowbeta gas-flow Geiger counter with a background of I 2 c.p.m. Tritium was assayed by evaporating samples to dryness in counting vials, washing with ethanol and evaporating to dryness again (twice). Scintillation solution $(5 \mathrm{ml}$; $12 \mathrm{~g}$./1. of Omnifluor in toluene) was added and the radioactivity counted in a Nuclear Chicago liquid scintillation counter model Unilux II with a background of 15 c.p.m.

\section{RESULTS}

Extent of DNA breakdown. Upon incubation at $37^{\circ}$, competent bacteria degrade I5 to $25 \%$ of adsorbed transforming DNA into acid-soluble material (Table I). This process is virtually complete within I $5 \mathrm{~min}$. Higher degradation values reported earlier (Stuy, 1965) probably reflect the lower quality of the DNA then used (as judged by slower sedimentation in sucrose gradients).

Table I. Degradation of irreversibly bound transforming DNA by Haemophilus influenzae in L-broth at $37^{\circ}$

\begin{tabular}{|c|c|c|c|}
\hline \multirow{2}{*}{$\begin{array}{l}\text { Incubation } \\
\text { time (min.) }\end{array}$} & \multicolumn{2}{|c|}{$\begin{array}{l}\text { Acid-soluble radioactivity as percentage } \\
\text { of total radioactivity }\end{array}$} & \multirow{2}{*}{$\begin{array}{l}\text { Loss of donor } \\
\text { str-r marker } \\
\text { activity in percentage } \\
\text { of zero time value }\end{array}$} \\
\hline & Suspension & Medium & \\
\hline 0 & 5 & 7 & 0 \\
\hline 5 & 14 & 14 & 48 \\
\hline 10 & 18 & 20 & 66 \\
\hline 20 & $2 \mathrm{I}$ & 22 & 75 \\
\hline 30 & 22 & 24 & 82 \\
\hline 40 & 24 & 26 & 82 \\
\hline
\end{tabular}

All incubation media tested: L-broth, Eugon broth, saline-Eugon broth (I0 \%, v/v), saline $+\mathrm{L}$-broth (I0 $\%, \mathrm{v} / \mathrm{v}$; competence medium), plain saline and chemically defined medium gave the same results. Nearly all of the degradation products were found in the medium (Table I). This was also observed for adsorbed phage $\lambda$ DNA (Newman \& Stuy, 1971).

The adsorbed transforming DNA rapidly lost about $80 \%$ of its activity (Table I). This suggests that it was more extensively damaged than the release of acid-soluble material indicates.

Nature of breakdown products. Our primary aim was to find out whether DNA degradation products included 5 ' deoxymononucleotides. For this reason we employed Dowex column chromatography and investigated a number of different incubation media. Experiments with ${ }^{32} \mathrm{P}$-labelled transforming DNA indicated that the acidsoluble fraction of the degradation products consisted of inorganic phosphate ( 25 to $45 \%$ ); small oligonucleotides ( 5 to $15 \%$ ), radioactivity eluted with either $\mathrm{HCl}$ or $\mathrm{NaOH}$ (Cohn, 1955), and larger oligonucleotides (radioactivity retained by the column). 
A typical experiment employing doubly labelled DNA is illustrated in Fig. I. It was found that neither the nature of the incubation medium nor the length of the incubation period had any significant effect on this distribution.

The absence of detectable amounts of mononucleotides might be explained by their rapid dephosphorylation. Indeed, competent bacteria and growing non-competent bacteria dephosphorylated about $70 \%$ of added mononucleotides $(80 \mu \mathrm{g} . / \mathrm{ml}$. of each) during $15 \mathrm{~min}$. of incubation as judged by the disappearance of the monophosphate peaks in subsequent chromatographic analysis. We then investigated the possibility that nucleotides added to the incubation medium would compete for dephosphorylation with the mononucleotides presumably formed by exonuclease action. DNA-treated bacteria were resuspended in saline containing $80 \mu \mathrm{g} . / \mathrm{ml}$. of each of the four nucleotides and incubated at $37^{\circ}$. Subsequent analysis of the acid-soluble degradation products again revealed no detectable amounts of deoxymononucleotides containing $\left[{ }^{32} \mathrm{P}\right] \mathrm{O}_{4}$.

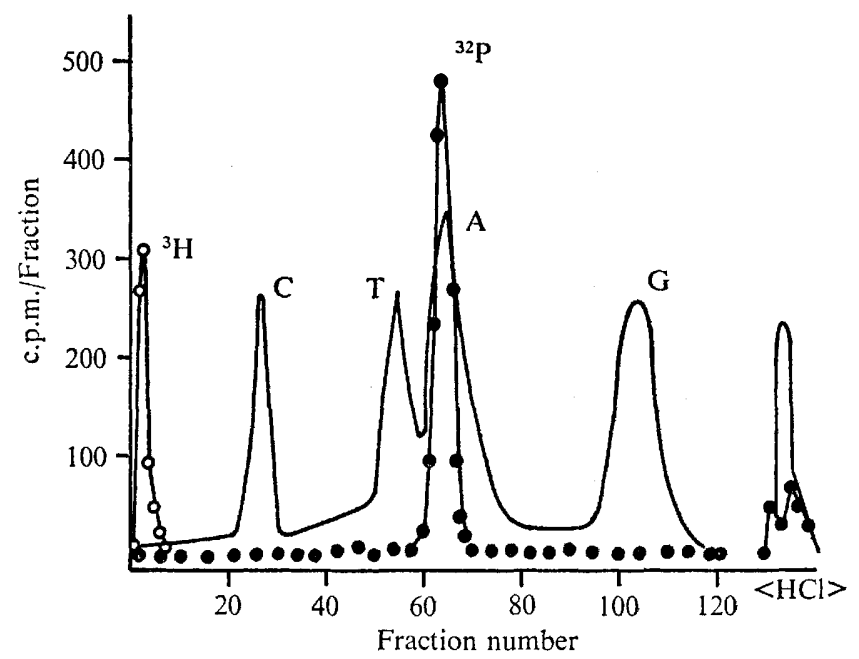

Fig. I. Dowex column chromatographic analysis of acid-soluble breakdown products produced from ${ }^{32} \mathrm{P}$ - and ${ }^{3} \mathrm{H}$-labelled transforming DNA irreversibly bound by Haemophilus influenzae. Post-DNA treatment incubation was in $0 \cdot 1 \mathrm{M}$-saline+Eugon broth $10 \%(\mathrm{v} / \mathrm{v})$. $\mathrm{O}$, ${ }^{3} \mathrm{H}$-radioactivity;,${ }^{32} \mathrm{P}$-radioactivity. No ${ }^{3} \mathrm{H}$-activity was found under the $\mathrm{C}$ and $\mathrm{T}$ peaks. $\mathrm{C}, \mathrm{T}, \mathrm{A}$ and $\mathrm{G}$ stand for deoxyribomononucleotides of cytosine, thymine, adenine and guanine, respectively.

When DNA-treated bacteria were incubated in L-broth for periods in excess of Io min., an additional acid-soluble ${ }^{32} \mathrm{P}$-labelled product was found. About $5 \%$ of the radioactivity eluted between ACMP and TMP. This fraction was found to contain considerable amounts of acid-labile phosphate. We interpreted it as inorganic phosphate entering cell metabolism as hexose phosphate. Lacks et al. (I967) observed a similar product which they identified as glycerol phosphate.

Our results so far show that one out of every 20 phosphate groups in the adsorbed DNA is released as inorganic phosphate. This could have been formed by dephosphorylation of endonuclease scission products or by dephosphorylation of exonuclease breakdown products. In the latter case we can expect considerable amounts of nucleoside material as degradation products. To investigate this we performed an 
experiment with ${ }^{32} \mathrm{P}$ - and ${ }^{3} \mathrm{H}$-labelled DNA. Bacteria were incubated in saline containing $10 \%$ Eugon broth (v/v) and examined prior to and after Io and $30 \mathrm{~min}$. of incubation. The chromatographic distribution of ${ }^{32} \mathrm{P}$-radioactivity in the acid-soluble fraction was found to be normal for the three samples. About $20 \%{ }^{3} \mathrm{H}$-radioactivity eluted before dCMP (Fig. I). No ${ }^{3} \mathrm{H}$-radioactivity eluted with TMP. Addition of the four mononucleotides to the incubation medium did not change this significantly: we found $22 \%$ 'nucleoside' material and $27 \%$ inorganic [ $\left.{ }^{32} \mathrm{P}\right]$ phosphate. These results thus suggest that a considerable fraction of the observed phosphate may have been formed through dephosphorylation of mononucleotides.

\section{DISCUSSION}

This study indicates that Haemophilus influenzae differs from Diplococcus pneumoniae in its mechanism of degrading irreversibly bound transforming DNA. In the case of $D$. pneumoniae nearly all the ${ }^{32}$ P-labelled DNA breakdown products were inorganic phosphate and mononucleotides (Lacks et al. 1967) and these authors conclude that the main mechanism of DNA degradation is exonuclease action. DNA breakdown products in the $H$. influenzae transformation system are inorganic phosphate ( 25 to $45 \%$ ), nucleosides or free bases (about $20 \%$ ) (see Carmody \& Herriott, 1970), small and large oligonucleotides. We did not observe even a trace of mononucleotides.

Our observations can be explained by assuming either the extensive action of an endonuclease together with a phosphatase or the action of an endonuclease, an exonuclease and a phosphatase. The large amount of inorganic phosphate suggests exonuclease activity. The question then arises: why were mononucleotides not seen even when surface phosphatase action was reduced by adding competing mononucleotides to the incubation medium? Perhaps the surface phosphatase was not involved in the breakdown process. In that case, the absence of even trace amounts of mononucleotides suggests that exonuclease and phosphatase acted in a co-operative way. We feel that we cannot make a definite conclusion at present concerning extensive exonuclease action in the breakdown of adsorbed transforming DNA.

Our conclusion concerning endonuclease action is mainly based on the presence of ${ }^{32} \mathrm{P}$-labelled material in the acid-soluble breakdown products that do not easily wash off the Dowex column and which is tentatively assumed to consist of oligonucleotides. It is indirectly based on the more extensive damage to DNA measured in terms of loss of transforming activity.

We considered it very important that all or nearly all the acid-soluble breakdown products were found in the medium. Thus DNA breakdown is either a cell surface phenomenon or it occurs inside the cell and is followed by complete excretion of the degradation products. We believe that the first explanation is more plausible.

The important question to be answered is whether degradation of adsorbed transforming DNA is an early step in the DNA integration process. The fact that breakdown may occur outside the cell argues against such a view unless DNA integration occurs at the cell surface. The greatly reduced degradation of adsorbed heterologous DNA (Newman \& Stuy, 197I) suggests that it may be. We believe, however, that studies such as the ones reported here and by Newman \& Stuy (197I) cannot give us a clear answer since they employ different DNAs. Transforming DNA, as we isolate it, 
is very heterogenous in size and in gene distribution over the DNA fragments. It may contain a considerable number of single-strand breaks. To study the response of competent bacteria to adsorption of homologous and of heterologous DNA, we should like to employ the same DNA and (nearly) the same recipient bacteria. We are now examining the possibility that the prophage transformation system (Stuy, I969) can fulfil these requirements.

This study was supported in part by a contract between Florida State University and the Division of Biology and Medicine of the United States Atomic Energy Commission.

\section{REFERENCES}

CARmody, J. M. \& Herriotr, R. M. (1970). Thymine and thymidine uptake by Haemophilus influenzae and the labelling of deoxyribonucleic acid. Journal of Bacteriology ror, 525-530.

CoHn, W. E. (1955). The separation of nucleic acid derivatives by chromatography on ion-exchange columns. In The Nucleic Acids, vol. I. New York: Academic Press.

Fox, M. S. \& AlLEN, M. K. (1964). On the mechanism of deoxyribonucleate integration in pneumococcal transformation. Proceedings of the National Academy of Sciences of the United States of America 52, 412-419.

Herriott, R. M., Meyer, E. Y., Vogt, M. \& Moda, M. (1970). Defined medium for growth of Haemophilus influenzae. Journal of Bacteriology Ior, 513-516.

LACKS, S. (1962). Molecular fate of DNA in genetic transformation of Pneumococcus. Journal of Molecular Biology 5, I I9-13 I.

LACKS, S., Greenberg, B. \& CARLson, K. (1967). Fate of donor DNA in pneumococcal transformation. Journal of Molecular Biology 29, 327-347.

Newman, C. M. \& StuY, J. H. (1971). Fate of bacteriophage $\lambda$ DNA after adsorption by Haemophilus influenzae. Journal of General Microbiology 65, I 53-1 59.

Notan, N. \& Goodgal, S. H. (1966). On the nature of recombinants formed during transformation in Haemophilus influenzae. Journal of General Physiology 49, 197-209.

StUY, J. H. (1962). Transformability of Haemophilus influenzae. Journal of General Microbiology 29, 537-549.

STUY, J. H. (1965). Fate of transforming DNA in the Haemophilus influenzae transformation system. Journal of Molecular Biology 13, 554-570.

STUY, J. H. (1969). Prophage mapping by transformation. Virology 38, 567-572. 